\title{
Three-dimensional cell cultivation systems
}

\author{
O. M. Sukach ${ }^{1,2}$, M. V. Shevchenko ${ }^{1}$ \\ ${ }^{1}$ Institute for Problems of Cryobiology and Cryomedicine, NAS of Ukraine \\ 23, Pereyaslavskaya Str., Kharkiv, Ukraine, 61015 \\ ${ }^{2}$ G. S. Skovoroda Kharkiv National Pedagogical University \\ 29, Alchevskyh Str., Kharkiv, Ukraine, 61002
}

This review discusses the characteristics of three-dimensional cell culture systems on and without carriers (scaffolds). Scaffolds are used to simulate the extracellular matrix, as well as to reproduce the natural physical and structural microenvironment of cells, similar to living tissue. The review examines the types of scaffolds (hard and gel-like, natural and artificial, degradable and non-degradable), their characteristics, advantages and disadvantages, features of cell distribution in them. The use of decellularized and devitalized organs and tissues as scaffolds is discussed. The review also considers matrix-free cultivation of cells in the composition of three-dimensional multicellular structures - spheroids. The structure and biology of spheroids is discussed. The features of spheroid formation under static (self-assembly) and dynamic (under the influence of external forces) cultivation conditions are considered. The role of spheroid size for cell survival is discussed.

Ke y w o r d s: cells, 3D cell culture, scaffolds, spheroids.

For many decades, mammalian cell cultures have been an invaluable tool in biology. The prevalent type of cell cultivation systems is a monolayer two-dimensional (2D) cell culture grown on rigid substrates (glass, polystyrene). However, they do not fully reproduce in vivo conditions. Cells in two-dimensional cultures are generally flatter and more elongated compared to cells in vivo. Cell cultivation under $2 \mathrm{D}$ conditions is also accompanied by selection of a specific cell phenotype adapted to growth on culture plastics or glass [1,2], cell polarity displacement [3], lack of nutrients and oxygen metabolic gradients, decrease in number of intercellular and cell-matrix interactions.

Unlike 2D monolayer cultures, most of the cells in tissues and organs are in the threedimensional (3D) environment, which consists of cellular and non-cellular components that provide various biophysical, biochemical and mechanical signals and are involved in the regulation of somatic and stem cell functions in vivo $[4,5]$. The non-cellular component, called the extracellular matrix (ECM), is a three-dimensional gel-like structure formed mainly by structural proteins (laminin, fibro-

(C) 2020 O. M. Sukach et al.; Published by the Institute of Molecular Biology and Genetics, NAS of Ukraine on behalf of Biopolymers and Cell. This is an Open Access article distributed under the terms of the Creative Commons Attribution License (http://creativecommons.org/licenses/by/4.0/), which permits unrestricted reuse, distribution, and reproduction in any medium, provided the original work is properly cited 
nectin and glycosaminoglycans). These proteins perform both structural and communicative functions, which ensure cellular interaction and maintenance of tissue specificity and homeostasis [6]. ECM also regulates the synthesis and release of soluble biomolecules and growth factors [6], provides the mechanical characteristics inherent in the cellular microenvironment $[7,8]$, and participates in the spatiotemporal control of cell migration $[7,8]$.

Cell interaction, as well as their interaction with ECM, are carried out through cell adhesion molecules located on the surface of the cell membrane and involved in numerous cellular processes, including recognition, adhesion, migration and cell differentiation. They are also responsible for transmitting information from ECM to the cell $[9,10]$. Depending on the structure and functions, cell adhesion molecules are divided into the immunoglobulin, integrin, cadherin and selectin families [11]. Intercellular interactions are mainly regulated by the cadherin protein family [12]. The proteins of integrin family are responsible for the binding of cells to ECM.

Noteworthy, the cellular microenvironment is a dynamic system that changes during the cells growth and development under the influence of spatio-temporal factors.

Thus the absence of three-dimensional cellular microenvironment results in the changes in morphology of cells [1, 2], their polarity [3], division mode, signaling pathways [13, 14], gene expression, biochemical processes [15, $16]$ and loss of their phenotype [17, 18]. Thereby at present the development of 3D culture methods that are maximally similar to in vivo conditions is an urgent task for researchers.
To fabricate the 3D microenvironment with physical, biological and mechanical characteristics of different types of tissues and cells, researchers use a wide range of materials and technological approach, which have both advantages and disadvantages. However, today there is no general approach for creating threedimensional cell models.

All existing 3D cultivation systems can be divided into 2 large groups: cell cultures on carriers or matrices and cell cultures without carriers.

\section{D Scaffold Cultivation Systems}

Three-dimensional matrices (scaffolds) are used to mimic ECM, as well as to reproduce the natural physical and structural microenvironment of cells, similar to living tissue [19]. Wherein, ideal scaffolds should provide attachment and migration of the cells, retain the biochemical factors, provide the oxygen and carbon dioxide diffusion as well as diffusion of nutrients and products expressed in cells, and exert specific mechanical and biological effects on cells. Scaffolds must also be characterized by high porosity and have pore sizes, ensuring efficient colonization and migration of the cells throughout their structure. A pattern to strive for is a scaffold porosity of $90 \%$ [20]. However, too high porosity can significantly impair the mechanical properties of the scaffold. The optimal pore size for different cells varies significantly [21]. For example, pores of 200-400 $\mu \mathrm{m}$ are effective for bone tissue formation [22], and pores of 50-200 $\mu \mathrm{m}$ are suitable for the growth of smooth muscle cells [23]. As a rule, the pores larger than $100 \mathrm{mi}-$ crons provide cell growth and scaffold vascularization. Too large pores ( $>400$ microns) 
reduce the number of intercellular contacts, since at this location the cells are closer to the conditions of 2D culture [24].

Depending on the physical properties and origin, scaffolds are divided into solid and gellike, as well as natural and artificial. Depending on the application [, the] scaffolds could be divided into degradable or non-degradable. The materials used for the manufacture of scaffolds must be non-toxic, biocompatible, non-immunogenic and thromboresistant.

Solid scaffolds are used in reconstructive medicine and preclinical in vitro testing of pharmaceutical preparations. In the first case, the cells are grown on carriers for possible in vivo transplantation to replace degenerative or altered tissue (bone, cartilage, ligaments, skin, blood vessels, and muscles) [25-27]. In the second case the scaffolds are used for modeling tumors or tissues in laboratory conditions [28].

Solid scaffolds are fabricated from a wide range of materials, including metals, ceramics, glass and polymers [29-32]. Depending on the structure, the solid scaffolds can be classified as networks, fibers, sponges, foams, etc. Such structures support a uniform spatial distribution of cells, their growth, diffusion of nutrients and metabolic products. For the production of solid scaffolds of various sizes, structures, stiffness, porosity and permeability, the polymers (Polyglycolide, Poly ( $\varepsilon$-caprolactone), Poly (ethylene oxide), Polybutylene terephthalate, Poly (L-lactic acid)) and their derivatives are most often used [32]. The manufacturing process for solid polymer scaffolds depends on the bulk and surface properties of the material and their intended use. Most production methods include applying heat and/or pressure to the polymer or its dissolving in an organic solvent to impart the material of a required shape. For the manufacture of scaffolds, the solution casting [33], leaching [34], electromolding [35] and 3D printing [36] technologies are used.

When fabricating scaffolds, it is considered that the scale and topography of their internal structures are an important factor for threedimensional cell culture. In the organism, the ECM is a complex nanoscale structure involved in the control of cell behavior [37, 38]. When bound to a scaffold, the cells usually spread and expand as if they were cultivated on a flat surface [39]. Therefore, even small changes in the nanoscale scaffold topography can have a significant effect on the cell behavior [40]. Cell attachment, growth and behavior are influenced not only by the scaffold microscale architecture and structure. The stiffness, permeability and mechanical properties of the scaffold, as well as the chemical properties of its surface, have a significant effect on these cell parameters [41]. Therefore, in order to improve cell adhesion, the surface of solid scaffolds is often modified by covering it with peptides (arginine-glycine-aspartic acid) [42], gelatin [43], and plasma proteins [44].

To colonize solid scaffolds with cells, two approaches are most often used: static and dynamic $[45,46]$. The most common methods of static colonization are surface seeding [47, $48]$ and direct insertion of cells into the scaffold $[49,50]$. Dynamic methods of seeding include forced filling of the scaffold with cells (by passing a solution with cells under pressure through the scaffold), which provides better cell penetration into the scaffold as well as their subsequent better growth compared to static colonization $[45,46]$. 
To assess the effectiveness of scaffold colonization, the attached cells are trypsinized, collected and analyzed using the MTT test [51], or cell lysate DNA analysis [52]. Unfortunately, none of these methods can provide complete information about the extent of cell expansion and the efficiency of their penetration into scaffolds.

The main disadvantages of using solid scaffolds in cell biology are the limited visualization of cells in matrices and the difficulties in extracting cells from a solid matrix.

Gel-like scaffolds or hydrogels are hydrophilic polymer networks capable of swelling but not dissolving in water, which makes them similar to the soft tissues of the body and a perfect kind of materials for tissue engineering [53-55]. Hydrogels are also highly permeable to oxygen, nutrients and metabolites [54-56].

Hydrogels are classified according to their ionic charge (neutral, cationic, anionic and ampholytic), structure (amorphous, semi-crystalline), and fabrication methods (homopolymer, copolymer, multipolymer) [54, 57]. By the origin of the polymer, hydrogels are divided into natural, synthetic, and hybrid (synthetic/natural) [53]. Depending on the mechanism of bond formation between the polymer chains, hydrogels could be divided into physical (hydrogen or hydrophobic bonds) and chemical (covalent bonds) [54, 58, 59]. The type and degree of chains crosslinking affect the hydrogels swelling, elastic modulus, permeability and stiffness [57].

Natural hydrogels are biologically active, compatible and biodegradable [60]. Due to the presence of various endogenous factors, contributing to the maintenance of viability, proliferation and differentiation of many types of cells, natural hydrogels are capable of stimulating many cellular functions [61].

To produce natural hydrogels, proteins (collagen, gelatin, fibrin, silk, lysozyme, elastin, calmodulin) [62-67], polysaccharides (hyaluronic acid, agarose, dextran, chitosan, heparin, alginate) [68-73], and DNA [74, 75] are used. Recently, protein scaffolds prepared from a mixture of proteins secreted by EngelbrethHolm-Swarm mouse sarcoma cells (consisting mainly of laminin, type IV collagen, enlactin, and various growth factors, which have received the commercial name Matrigel) have become widespread [76].

Protein-based hydrogels can be obtained by thermal exposure to proteins, as well as by the use of chemical crosslinking agents. Thus, Matrigel, being liquid at $4{ }^{\circ} \mathrm{C}$, turns into a gel at $37^{\circ} \mathrm{C}$.

Polysaccharide hydrogels can be produced by covalent crosslinking, esterification and polymerization. The polysaccharides can also be combined with proteins $[77,78]$.

DNA is able to form hydrogel networks through self-assembly, electrostatic interaction, chemical crosslinking, or enzymatic ligation $[74,75]$. The properties of these hydrogels depend on the initial concentrations and types of DNA monomers [79].

Most hydrogels can also be obtained by photopolymerization [59, 80].

The disadvantages of natural hydrogels are their potential immunogenicity, probability of disease transmission, inconstancy of composition and relatively poor mechanical properties $[1,2,18]$.

Synthetic hydrogels are fabricated completely from synthetic molecules such as polyethylene glycol (Poly (ethylene glycol), poly- 
vinyl alcohol (Polyvinyl alcohol), and poly2-hydroxyethyl methacrylate, polylactic acid (Polylactide) [81-84]. They are biologically inert, but provide structural support for various types of cells. Compared to natural ones, synthetic hydrogels have more reproducible physical and chemical properties, which is crucial for tissue engineering. The synthetic polymers used in the production of hydrogels can be divided into non-biodegradable [85] and biodegradable [86].

Biodegradable synthetic hydrogels are used to make vascular structures or soft tissues, whereas non-biodegradable ones are used to construct bones and cartilages.

Although synthetic hydrogels can maintain the viability of encapsulated cells based on feasibility of ECM formation [87], most of them usually function only as passive scaffolds that do not promote active cellular interactions [88]. To eliminate this drawback, biologically active molecules and proteins (promoting cell adhesion, migration, proliferation, and differentiation) are included in the composition of synthetic hydrogel networks $[58,89]$.

In hybrid hydrogels obtained by combining synthetic hydrogels with natural polymers, the synthetic unit provides customizable physical properties, and the natural one provides specific biological functions.

To colonize hydrogels, the cells are either mixed with the initial components of a liquid scaffold before its formation $[3,90]$, or added to previously formed scaffolds.

After colonization, the cells can reconstruct their microenvironment by producing signaling molecules and ECM molecules. The cells are also capable of migration, proliferation, and differentiation. The ideal final result is the formation of stable homeostatic state of the cells, similar to intact tissue.

In contrast to solid scaffolds, the use of hydrogels allows the formation of multilayer tissue-like structures. Thus, for example, certain types of cells are embedded in separate hydrogel constructions, which are then superimposed on each other, thus forming layers similar to tissues in vivo [91].

In addition to artificially manufactured (scaffolds from natural or synthetic components), researchers use decellularized and devitalized organs and tissues as scaffolds [92]. In this type of natural tissue scaffolds, after removal of all cellular components that can cause an inflammatory reaction, the extant ECM retains its composition, architecture, integrity, biomechanical properties, biological activity, hemocompatibility as well as the ability to control cell migration, tissue-specific gene expression and cell fate. The decellularized material can maintain the integrity of the entire organ or its part, or can be subjected to further enzymatic treatment in order to transfer it to a liquid with subsequent formation of ECM-containing hydrogel. After decellularization and certain processing, these natural 3D scaffolds can be functionalized by repeated recellularization with the specific stem or somatic cells together with the necessary growth factors [92]. The sources for creating such natural scaffolds can be the organs and tissues of both humans and animals.

\section{Matrix-Free 3D Cultivation Methods}

In addition to the 3D cultivation systems using matrices (scaffolds), the matrix-free cell cultivation as a part of three-dimensional multi- 
cellular structures (aggregates and spheroids) has become widespread.

The ability to form three-dimensional multicellular structures is based on the tendency of cells with three equivalent degrees of freedom towards aggregation in the absence of substrates, and on the subsequent active formation of intercellular contacts and (micro)structures with a minimum surface/volume ratio, i.e. spheroids. Spheroids are characterized by diffusion of oxygen, nutrients and metabolic products inherent to living tissues [93]. In spheroids, the microenvironment signals are restored simultaneously with a decrease in metabolic rates and reduction in the consumption of ATP and oxygen [94]. This is associated with an increase in cell survival in the composition of spheroids. In addition to an increase in the survival time of functionally active cells, the configuration of spheroids (due to the minimum surface to volume ratio) allows one to achieve cell density per unit volume comparable with cell density in organs [95]. Moreover, many cells within the spheroid take the most energy-efficient spherical shape [96], which, according to some researchers, can induce the reexpression of earlier genes, as well as the activation of cell regeneration genes [97].

The advantage of spheroids over more complex 3D scaffold-based matrix systems is the simpleness of their analysis by visualization using light, fluorescence and confocal microscopy.

Spheroid Formation Methods. Almost all methods for generating spheroids include 3 main stages: formation of loose cell aggregates; induction of cadherin expression, during which cell aggregates condense; compaction of aggregates resulting in formation of spheroids. The formation of loose aggregates, as a rule, occurs during cultivation at high cell density $\left(0.5-4 \times 10^{6}\right.$ cells $\left./ \mathrm{ml}\right)$ under conditions that prevent or impede the attachment of cells to the substrate. In this case, the formation of loose aggregates occurs with the participation of both cadherins and integrins. The intercellular contacts formed during the aggregation process lead to an increase of cadherin expression, which accumulates on the membrane surface. Further, due to the intensification of cadherin mediated intercellular interactions, a morphological transition occurs from loose cell aggregates to compact spheroids [98].

The methods for the formation of spheroids can be divided into static - cell self-assembly, and dynamic - assembly of cells based on forced collisions (Table). Self-assembly is a process that takes place in a static environment in which cells cannot attach to the surface and thus come into contact with each other, forming aggregates.

The formation of spheroids during self-assembly can occur during cell cultivation on adhesive [99] and non-adhesive [100-103] surfaces, as well as in the absence of an attachment surface (hanging drop culture, [104, 105] emulsion technologies [106]).

In dynamic conditions, the formation of spheroids occurs under the influence of external forces [107-111], when, preventing the attachment of cells to the substrate, their collision and subsequent adhesion are initiated. Gravitational and centrifugal forces [107, 108, $110,112]$, magnetic [109] and electric [113] fields, as well as acoustic waves [111] (Table) can be used as external forces. At the same time, as previously noted, a prerequisite for 
spheroid formation, regardless of the methods used, is cultivation at high cell density $(0.5-$ $4 \times 10^{6}$ cells $/ \mathrm{ml}$ ).

All methods for the formation of spheroids have both advantages and disadvantages (Table). Among the disadvantages, it should be noted the difficulty of obtaining a sufficiently large number of spheroids (standard in size and shape) during short time, at low cost of labor and means.

The methods of self-assembly on adhesive and non-adhesive surfaces are simple, inexpensive, well reproducible, allowing the production of a large number of spheroids. However, they are characterized by high variability of spheroids' shape and size and are applicable only to certain types of cells.

Using the "hanging drop" method and emulsion technologies allows obtaining of standard size spheroids in a controlled microenvironment, but at the same time these methods are highly labor intensive, require special equipment, and the forming spheroids are characterized by small sizes. The "hanging drop" method also does not allow obtaining a sufficiently large number of spheroids [104, 105].

The use of various types of rotation and rocking are simple and high productivity methods that provide good conditions for delivery of nutrients and oxygen, removal of waste products, possibility of long-term cultivation in a controlled microenvironment $[107,108]$. However, these methods do not allow obtaining spheroids of standard size and shape. A significant part of the spheroids is characterized by large sizes, which is accompanied by the death of a part of the cells.

The use of magnetic and electric fields, as well as acoustic waves makes it possible to obtain spheroids of a controlled size and shape from various types of cells in a short period of time [109, 111, 113]. However, the cell aggregates may lose their integrity after the removal of "force". Additionally, the influence of "external force" can lead to cell damage.

An important parameter of the formed spheroids is their size, which, depending on the production methods, can vary over a wide range - from 50 to $1000 \mu \mathrm{m}$. It was found that cell viability decreases with an increase of the spheroid size [114]. This is explained by the fact that an increase of spheroid size is accompanied by formation of gas and substance distribution gradients $[115,116]$. This leads to both the impaired diffusion of oxygen and nutrients to the central cells, and the accumulation of carbon dioxide and waste products in them. Such processes occurring in large spheroids lead to the formation of several cell layers: a necrosis zone, located in the center and consisting of dead cells; a zone of living cells in a resting state; and an outer zone consisting of viable, metabolically active cells [117]. Thus, there is a necessity to determine the sizes of spheroids that ensure maximum cell viability and productivity. Numerous studies have shown that the spheroids with a diameter up to $100 \mu \mathrm{m}$ are characterized by a low risk of developing hypoxic conditions $[115,116,118]$. In contrast, the spheroids with a diameter exceeding $200 \mu \mathrm{m}$ are at an increased risk of oxygen deficiency in the central zone, leading to cell death $[117,118]$.

The dynamic cultivation conditions contribute to an increase of the diffusion rates of oxygen, nutrients and metabolites, which allows enlarging the size of spheroids consisting 
entirely of viable cells. In order to ensure continuous supply of oxygen to the spheroids during cultivation, special gas-permeable chips have also been developed [119]. They provide an opportunity to increase the size of spheroids consisting of viable cells up to $600 \mu \mathrm{m}$.

\section{Conclusion}

Thus, the development of three-dimensional cultivation systems has become an important step towards the creation of cell models that, by their characteristics, are closer to intact tissues in vivo. However, unlike 2D cultivation systems, there is still no standard approach for 3D cultivation systems. Noteworthy, the de- velopment of such a universal approach is challenging because of the complexity of ECM composition and structure, the physiological characteristics of different types of cells, the specificity of mechanical properties, biochemical signals, intercellular and cell-matrix connections in different tissues.

The matrix 3D cultivation systems allow the development of structures that, due to their mechanical properties, porosity and biological activity, mimic living tissues in vivo. Nevertheless, biochemical signals and, mainly intercellular and cell-matrix bonds in these structures can differ significantly from natural ones. Moreover, the cell cultivation in scaf-

Table. Methods for multicellular spheroids formation.

\begin{tabular}{|c|c|c|c|c|}
\hline \multicolumn{3}{|l|}{ Method } & Advantages & Disadvantages \\
\hline \multirow[t]{4}{*}{ Static } & \multirow[t]{4}{*}{$\begin{array}{l}\text { Cultivation } \\
\text { on non- } \\
\text { adhesive } \\
\text { surfaces and } \\
\text { in hanging } \\
\text { drop }\end{array}$} & Polymer coating [100-10 3] & $\begin{array}{l}\text { - low cost } \\
\text { - simplicity of the procedure } \\
\text { - availability } \\
\text { - reproducibility } \\
\text { - high productivity }\end{array}$ & $\begin{array}{l}\text { - MCS size and shape } \\
\text { variability } \\
\text { - laboriousness } \\
\text { - lack of cell-matrix } \\
\text { interaction }\end{array}$ \\
\hline & & Hanging drop [104] & \multirow{3}{*}{$\begin{array}{l}\text { - standard size of MCS } \\
\text { - controlled microenvironment } \\
\text { - reproducibility }\end{array}$} & \multirow{3}{*}{$\begin{array}{l}\text { - laboriousness } \\
\text { - small size of MCS } \\
\text { - the difficulty of obtaining } \\
\text { large quantities of MCS } \\
\text { - use of special equipment }\end{array}$} \\
\hline & & $\begin{array}{l}\text { Super Hydrophobic Chips } \\
{[105]}\end{array}$ & & \\
\hline & & Emulsion technology [106] & & \\
\hline \multirow[t]{6}{*}{ Dynamic } & \multirow{6}{*}{$\begin{array}{l}\text { Action of } \\
\text { external } \\
\text { forces }\end{array}$} & $\begin{array}{l}\text { Rotating cell culture system } \\
{[107,108]}\end{array}$ & \multirow{2}{*}{$\begin{array}{l}\text { - simplicity of the method } \\
\text { - high productivity } \\
\text { - long-term cultivation } \\
\text { - control of microenvironment }\end{array}$} & \multirow{2}{*}{$\begin{array}{l}\text { - MCS shape and size } \\
\text { variability } \\
\text { - MCS damage } \\
\text { - lack of cell-matrix } \\
\text { interaction }\end{array}$} \\
\hline & & $\begin{array}{l}\text { Rocked cell culture system } \\
{[110]}\end{array}$ & & \\
\hline & & Magnetic field [109] & \multirow{4}{*}{$\begin{array}{l}\text { - MCS size and shape control } \\
\text { - applicability to various types } \\
\text { of cells for MCS formation } \\
\text { - co-cultivation of various types } \\
\text { of cells for MCS formation } \\
\text { - fast MCS formation }\end{array}$} & \multirow{4}{*}{$\begin{array}{l}\text { - loss of MCS integrity } \\
\text { after the removal of } \\
\text { "power" } \\
\text { - cell damage due to } \\
\text { external force } \\
\text { - lack of cell-matrix } \\
\text { interaction }\end{array}$} \\
\hline & & Electric field [113] & & \\
\hline & & & & \\
\hline & & Acoustic waves [111] & & \\
\hline
\end{tabular}


folds can often be characterized as $2 \mathrm{D}$ in $3 \mathrm{D}$, since the cells in three-dimensional surface of the scaffolds attach, spread and migrate in the same way as the cells cultured under adherent two-dimensional conditions.

In multicellular spheroids, the intercellular contacts similar to tissues are reproduced as well as the gradients of oxygen, carbon dioxide, nutrients and metabolic products. However, in spheroids, as a rule, there is a lack of cellmatrix interaction. It is not completely clear which cells assemble into spheroids and what is the degree of conformity between the structure and composition of ECM formed in spheroids and the natural one. In spheroids, as well as in matrix cultures, the cellular signaling pathways differ from signaling pathways in tissues in vivo, which also causes differences in the behavior of cells in spheroids compared with the behavior of living tissues cells. The optimal size of the spheroids, on which the metabolism, gene expression, and stem characteristics of cells depend, is also indeterminate. The influence of spheroid formation methods on the state and properties of cells is inexplicit. Thus, for example, the spontaneously formed spheroids probably consist of comparably homogeneous population of cells capable of aggregation, whereas the forcedly generated spheroids apparently contain different types of cells.

Currently, the efforts of numerous researchers are aimed at resolving these complex issues. New 3D cultivation systems and new approaches are being developed, including the combining of matrix cultivation systems with matrixless ones, as well as the bioprinting using spheroids, natural and artificial matrices.

\section{REFERENCES}

1. Mahmud G, Campbell CJ, Bishop KJM, Komarova YA, Chaga O, Soh $S$, Huda S, Kandere-Grzybowska K, Grzybowski B A. Directing cell motions on micropatterned ratchets. Nat Phys. 2009; 5:606-12.

2. Kilian K, Bugarija B, Lahn BT, Mrksich M. Geometric cues for directing the differentiation of mesenchymal stem cells. Proc Natl Acad Sci USA. 2010; 107(11):4872-7.

3. Mseka T, Bamburg JR, Cramer LP. ADF/cofilin family proteins control formation of oriented actin-filament bundles in the cell body to trigger fibroblast polarization. J Cell Sci. 2007; 120(Pt 24):4332-44.

4. Lane SW, Williams DA, Watt FM. Modulating the stem cell niche for tissue regeneration. Nat Biotechnol. 2014; 32(8):795-803.

5. Donnelly H, Salmeron-Sanchez M, Dalby MJ. Designing stem cell niches for differentiation and selfrenewal. J R Soc Interface. 2018; 15(145):20180388.

6. Kleinman HK, Philp D, Hoffman MP. Role of the extracellular matrix in morphogenesis. Cur Opin Biotechnol. 2003; 14(5):526-32.

7. Hynes $R O$. The extracellular matrix: not just pretty fibrils. Science. 2009; 326(5957):1216-19.

8. Daley WP, Peters SB, Larsen M. Extracellular matrix dynamics in development and regenerative medicine. Journal of cell science. 2008; 121(Pt 3):255-64.

9. Edelman G. Cell adhesion molecules. Science. 1983; 219(4584):450-57.

10. Homrich M, Gotthard I, Wobst H, Diestel S. Cell adhesion molecules and ubiquitination functions and significance. Biology (Basel). 2016; 5(1):1.

11. Hynes RO. Cell adhesion: old and new questions. Trends Cell Biol. 1999; 9(12): M33-M37.

12. Halbleib JM, Nelson WJ. Cadherins in development: cell adhesion, sorting, and tissue morphogenesis. Genes Dev. 2006; 20(23):3199-214.

13. Nelson CM, Bissell MJ. Of extracellular matrix, scaffolds, and signaling: tissue architecture regulates development, homeostasis, and cancer. Annu Rev Cell Dev Biol. 2006; 22:287-309. 
14. Meyers J, Craig J, Odde DJ. Potential for control of signaling pathways via cell size and shape. Curr Biol. 2003; 16(17):1685-93.

15. Birgersdotter A, Sandberg R, Ernberg I. Gene expression perturbation in vitro - a growing case for three-dimensional (3D) culture systems. Semin Cancer Biol. 2005; 15(5): 405-12.

16. Gomez-Lechon M, Jover R, Donato T, Ponsoda X, Rodriquez C, Stenzel KG, Klocke R, Paul D, Guillen L, Bort R, Castell JV. Long-term expression of differentiated functions in hepatocytes cultured in three-dimensional collagen matrix. J Cell Physiol. 1998; 177(4):553-62.

17. von der Mark K, Gauss V, von der Mark H, Muller P. Relationship between cell shape and type of collagen synthesized as chondrocytes lose their cartilage phenotype in culture. Nature. 1977; 267:531-2.

18. Petersen OW, Ronnov-Jessen L, Howlett AR, Bissel $M J$. Interaction with basement membrane serves to rapidly distinguish growth and differentiation pattern of normal and malignant human breast epithelial cells. Proc Natl Acad Sci USA. 1992; 89(19):9064-8.

19. Tan W, Krishnaraj R, Desai TA. Evaluation of nanostructured composite collagen-chitosan matrices for tissue engineering. Tissue Eng. 2001; 7(2):203-10.

20. Shruti S, Salinas AJ, Lusvardi G, Malavasi G, Menabue L, Vallet-Regi M. Mesoporous bioactive scaffolds prepared with cerium-, gallium- and zinc-containing glasses. Acta Biomater. 2013; 9(1):4836-44.

21. Wei G, Ma PX. Structure and properties of nanohydroxyapatite/polymer composite scaffolds for bone tissue engineering. Biomaterials. 2004; 25(19):4749-57.

22. Boyan BD, Hummert TW, Dean DD, Schwartz Z. Role of material surfaces in regulating bone and cartilage cell response. Biomaterials. 1996; 17(2):137-46.

23. Lee $M$, Wu BM, Dunn JC. Effect of scaffold architecture and pore size on smooth muscle cell growth. $J$ Biomed Mater Res A. 2008; 87(4):1010-16.

24. Marrella A, Lee TY, Lee DH, Karuthedom S, Syla D, Chawla A, Khademhosseini A, Jang HL. Engineering vascularized and innervated bone biomaterials for improved skeletal tissue regeneration. Mater. Today. 2018; 21(4):362-76.

25. Dhandayuthapani B, Yoshida Y, Maekawa T, Kumar DS. Polymeric scaffolds in tissue engineering application: A review. Int. J. Polym. Sci. 2011; 2011:290602.

26. Lee P, Tran K, Chang W, Fang Y-L, Zhou G, Junka R, Shelke NB, Yu X, Kumbar SG. Bioactive polymeric scaffolds for osteochondral tissue engineering: in vitro evaluation of the effect of culture media on bone marrow stromal cells. Polym. Adv. Technol. 2015; 26(12):1476-85.

27. Lee P, Tran K, Zhou G, Bedi A, Shelke NB, Yu X, Kumbar $S G$. Guided differentiation of bone marrow stromal cells on co-cultured cartilage and bone scaffolds. Soft Matter. 2015; 11:7648-55.

28. Caicedo-Carvajal CE, Liu Q, Remache Y, Goy A, Suh $K S$. Cancer tissue engineering: A novel 3D polystyrene scaffold for in vitro isolation and amplification of lymphoma cancer cells from heterogeneous cell mixtures. J Tissue Eng. 2011; 2011:362326.

29. Surmeneva MA, Surmenev RA, Chudinova EA, Koptioug A, Tkachev MS, Gorodzha SN, Rännar L-E. Fabrication of multiple-layered gradient cellular metal scaffold via electron beam melting for segmental bone reconstruction. Mater Des. 2017; 133:195-204.

30. Hench $L L$. Bioceramics: from concept to clinic. $J$ Am Ceram Soc. 1991; 74(7):1487-510.

31. Fielding GA, Bandyopadhyay A, Bose S. Effects of silica and zinc oxide doping on mechanical and biological properties of 3D printed tricalcium phosphate tissue engineering scaffolds. Dent Mater. 2012; 28(2):113-22.

32. Lee J, Cuddihy MJ, Kotov NA. Three-dimensional cell culture matrices: state of the art. Tissue engineering. Part B, Reviews. 2008; 14(1):61-86.

33. Sin DC, Miao X, Liu G, Wei F, Chadwick G, Yan C, Friis $T$. Polyurethane (PU) scaffolds prepared by solvent casting/particulate leaching (SCPL) combined with centrifugation . Mat Sci Eng C. 2010; 30(1):78-85.

34. Chen J, Ye J, Liao X, Li S, Xiao W, Yang $Q, L i G$. Organic solvent free preparation of porous scaffolds 
based on the phase morphology control using supercritical $\mathrm{CO}_{2}$. J Supercrit Fluid. 2019; 149:88-96.

35. Um C, Fang D, Hsiao B. S, Okamoto A, Chu B. Electro-spinning and electro-blowing of hyaluronic acid. Biomacromolecules 2004; 5(4):1428-36.

36. Ge Z, Tian X, Heng BC, Fan V, Yeo JF, Cao T. Histological evaluation of osteogenesis of 3Dprinted polylactic-co-glycolic acid (PLGA) scaffolds in a rabbit model. Biomed Mater. 2009; 4(2):021001.

37. Zagris $N$. Extracellular matrix in development of the early embryo. Micron. 2001; 32(4):427-38.

38. Aumailley M, Gayraud B. Structure and biological activity of the extracellular matrix. J Mol Med.1998; 76(3-4):253-65.

39. Stevens $M M$, George JH. Exploring and engineering the cell surface interface. Science.2005; 310(5751):1135-8.

40. Curtis A, Wilkinson C. New depths in cell behaviour: reactions of cells to nanotopography. Biochem Soc Symp. 1999; 65:15-26.

41. Haycock JW. 3D cell culture: a review of current approaches and techniques. Methods Mol Biol. 2011; 695: $1-15$.

42. Lan PX, Lee JW, Seol Y-J, Cho D-W. Development of 3D PPF/DEF scaffolds using micro-stereolithography and surface modification. J Mater Sci Mater Med. 2009; 20(1):271-9.

43. Liu $X$, Won $Y$, Ma PX. Porogen-induced surface modification of nano-fibrous poly(L-lactic acid) scaffolds for tissue engineering. Biomaterials. 2006; 27(21):3980-7.

44. Siow K, Britcher L, Kumar S, Griesser H. Plasma methods for the generation of chemically reactive surfaces for biomolecule immobilisation and cell colonisation - a review. Plasma Process Polym. 2006; 3(6-7):392-418.

45. Zhao F, Ma T. Perfusion bioreactor system for human mesenchymal stem cell tissue engineering: dynamic seeding and construct development. Biotechnol Bioeng. 2005; 91 (4):482-93.

46. van den Dolder J, Spauwen PH, Jansen JA. Evaluation of various seeding techniques for culturing osteogenic cells on titanium fiber mesh. Tissue Eng. 2003; 9(2):315-25.
47. Choong CS, Hutmacher DW, Triffitt JT. Co-culture of bone marrow fibroblasts and endothelial cells on modified polycaprolactone substrates for enhanced potentials in bone tissue engineering. Tissue Eng. 2006; 12(9):2521-31.

48. Wan Y, Wang Y, Liu Z, Qu X, Han B, Bei J, Wang S. Adhesion and proliferation of OCT-1 osteoblastlike cells on micro- and nano-scale topography structure poly(L-lactide). Biomaterials. 2005; 26(21):4453-9.

49. Honda MJ, Yada T, Ueda M, Kimata K. Cartilage formation by serial passaged cultured chondrocytes in a new scaffold: hybrid 75:25 poly(L-lactide-epsilon-caprolactone) sponge. J Oral Maxillofac Surg. 2004; 62(12):1510-6.

50. Hofmann A, Konrad L, Gotzen L, Printz H, Ramaswamy A, Hofmann $C$. Bioengineering human bone tissue using autogenous osteoblasts cultured on different biomatrices. J Biomed Mater Res A. 2003; 67(1):191-9.

51. Shen H, Hu X, Yang F, Bei J, Wang S. Combining oxygen plasma treatment with anchorage of cationized gelatin for enhancing cell affinity of poly(lactide-co-glycolide). Biomaterials. 2007; 28(29):4219-30.

52. Spalazzi JP, Doty SB, Moffat KL, Levine $W N$, $\mathrm{Lu} \mathrm{HH}$. Development of controlled matrix heterogeneity on a triphasic scaffold for orthopedic interface tissue engineering. Tissue Eng. 2006; 12(12):3497-508.

53. Zhu J, Marchant RE. Design properties of hydrogel tissue-engineering scaffolds. Expert Rev Med Devices. $2011 ; 8(5): 607-26$.

54. Slaughter BV, Khurshid SS, Fisher OZ, Khademhosseini A, Peppas NA. Hydrogels in regenerative medicine. Adv Mater. 2009; 21(32-33):3307-29.

55. Cushing MC, Anseth KS. Hydrogel cell culture. Science. 2007; 316(5828):1133-4.

56. Nuttelman CR, Rice MA, Rydholm AE, Salinas $C N$, Shah DN, Anseth KS. Macromolecular monomers for the synthesis of hydrogel niches and their application in cell encapsulation and tissue engineering. Prog Polym Sci. 2008; 33(2):167-70.

57. Hoffman $A S$. Hydrogels for biomedical applications. Adv Drug Deliver Rev. 2002; 43(1):3-12. 
58. Liu SQ, Tay R, Khan M, Ee PLR, Hedrick JL, Yang YY. Synthetic hydrogels for controlled stem cell differentiation. Soft Matter. 2010; 6(1):67-81.

59. Nguyen TK, West JL. Photopolymerizable hydrogels for tissue engineering applications. Biomaterials. 2002; 23(22):4307-14.

60. Dawson E, Mapili G, Erickson K, Taqvi S, Roy K. Biomaterials for stem cell differentiation. Adv Drug Deliv Rev. 2008; 60(2):215-28.

61. Tibbitt MW, Anseth KS. Hydrogels as extracellular matrix mimics for 3D cell culture. Biotechnol Bioeng. $2009 ; 103(4)$ :655-63.

62. Sengupta D, Heilshorn S. Protein-engineered biomaterials: Highly tunable tissue engineering scaffolds. Tissue Eng Part B Rev. 2010; 16(3):285-93.

63. MacEwan SR, Chilkoti A. Elastin-like polypeptides: biomedical applications of tunable biopolymers. Pept Sci. 2010; 94(1):60-77.

64. Romano NH, Sengupta D, Chung C, Heilshorn SC. Protein-engineering biomaterials: nanoscale mimcs of the extracellular matrix. Bioichim Biophy Acta. 2011; 1810(3):339-49.

65. Greish K, Araki K, Li D, O'Malley Jr BW, Dandu R, Frandsen J, Cappello J, Ghandeharia H. Silk-elastinlike protein polymer hydrogels for localized adenoviral gene therapy of head and neck tumors. Biomacromolecules. 2009; 10(8):2183.

66. Banta $S$, Wheeldon IR, Blenner M. Protein engineering in the development of functional hydrogels. Annu Rev Biomed Eng. 2010; 12:167-186.

67. Kaufmann D, Fiedler A, Junger A, Auernheimer J, Kessler H, Weberskirch R. Chemical conjugation of linear and cyclic RGD moieties to a recombinant elastin-mimetic polypeptide - a versatile approach towards bioactive protein hydrogels. Macromol Biosci. 2008; 8(6):577-88.

68. Leach JB, Bivens KA, Patrick CW, Schmidt CE. Photocrosslinked hyaluronic acid hydrogels: Natural, biodegradable tissue engineering scaffolds. Biotechnol Bioeng. 2003; 82(5):578-89.

69. Ramamurthi A, Vesely I. Ultraviolet light-induced modification of crosslinked hyaluronan gels. J Biomed Mater Res A. 2003; 66(2):317-29.

70. Denizli BK, Can HK, Rzaev ZMO, Guner A. Preparation conditions and swelling equilibria of dextran hydrogels prepared by some crosslinked agents. Polymer. 2004; 45(19):6431-35.

71. Kuо $C K, M a P X$. Ionically crosslinked alginate hydrogels as scaffolds for tissue engineering: part I. Structure, gelation rate and mechanical properties. Biomaterials. 2001; 22(6):511-21.

72. Kim IY, Seo SJ, Moon HS, Yoo MK, Park IY, Kim BC, Cho CS. Chitosan and its derivatives for tissue engineering applications. Biotechnol Adv. 2008; 26(1):1-21.

73. Liang Y, Liu W, Han B, Yang C, Ma Q, Song F, Bi $Q$. An in situ formed biodegradable hydrogel for reconstruction of the corneal endothelium. Colloids Surf B. 2011; 82(1):1-7.

74. Um SH, Lee JB, Park N, Kwon SY, Umbach CC, Luo D. Enzyme-catalysed assembly of DNA hydrogel. Nat Mater. 2006; 5(10):797-801.

75. Xing Y, Cheng E, Yang Y, Chen P, Zhang T, Sun Y, Yang $Z$, Liu D. Self-assembled DNA hydrogels with designable thermal and enzymatic responsiveness. Adv Mater. 2011; 23(9):1117-21.

76. Kleinman HK, Martin GR. Matrigel: basement membrane matrix with biological activity. Semin Cancer Biol. 2005; 15(5):378-86.

77. Bavaresco B, Comín R, Salvatierra NA, Cid MP. Three-dimensional printing of collagen and hyaluronic acid scaffolds with dehydrothermal treatment crosslinking. Compos. Commun. 2020; 19:1-5.

78. Dhandayuthapani B, Krishnan UM, Sethuraman $S$. Fabrication and characterization of chitosangelatin blend nanofiber for skin tissue engineering. J Biomed Mater Res B Appl Biomater. 2010; 94(1):264-72.

79. Lee CK, Shin SR, Lee SH, Jeon JH, So I, Kang TM, Kim SI, Mun JY, Han SS, Spinks GM, Wallace GG, Kim SJ. DNA hydrogel fiber with self-entanglement prepared by using an ionic liquid. Angew Chem Int Ed. 2008; 47(13):2470-4.

80. Ifkovits JL, Burdick JA. Review: photopolymerizable and degradable biomaterials for tissue engineering applications. Tissue Eng. 2007; 13(10):2369-85.

81. Sawhney AS, Pathak CP, Hubbell JA. Bioerodible hydrogels based on photopolymerized poly(ethylene glycol)-co-poly(.alpha.-hydroxy acid) diacrylate macromers. Macromolecules. 1993; 26:581-7. 
82. Martens $P$, Anseth KS. Characterization of hydrogels formed from acrylate modified poly(vinyl alcohol) macromers. Polymer. 2000; 41:7715-22.

83. Atzet $S$, Curtin S, Trinh P, Bryant $S$, Ratner $B$. Degradable poly(2-hydroxyethyl methacrylate)co-polycaprolactone hydrogels for tissue engineering scaffolds. Biomacromolecules. 2008; 9(12):3370-7.

84. HyukIm S, JeongPark Su, Chung JJ, Jung Y, HyunKim $S$. Creation of polylactide vascular scaffolds with high compressive strength using a novel melttube drawing method. Polymer. 2019; 166:130-7.

85. Yang F, Williams CG, Wang D, Lee H, Manson $P N$, Elisseeff $J$. The effect of incorporating RGD adhesive peptide in polyethylene glycol diacrylate hydrogel on osteogenesis of bone marrow stromal cells. Biomaterials. 2005; 26(30):5991-8.

86. Atzet $S$, Curtin S, Trinh P, Bryant S, Ratner B. Degradation poly(2-hydroxyl methacrylate)-co-polycaprolactone hydrogels for tissue engineering scaffolds. Biomacromolecules. 2008; 9(12):3370-7.

87. Bryant SJ, Anseth KS. Hydrogel properties influence ECM production by chondrocytes photoencapsulated in poly(ethylene glycol) hydrogels. $J$ Biomed Mater Res. 2002; 59(1):63-72.

88. Tan H, Marra KG. Injectable, biodegradable hydrogels for tissue engineering applications. Materials (Basel). 2010; 3(3):1746-67.

89. Zhu J. Bioactive modification of poly(ethylene glycol) hydrogels for tissue engineering. Biomaterials. 2010; 31(17):4639-56.

90. Fisher KE, Pop A, Koh W, Anthis NJ, Saunders WB, Davis GE. Tumor cell invasion of collagen matrices requires coordinate lipid agonist-induced G-protein and membrane-type matrix metalloproteinase-1-dependent signaling. Mol Cancer. 2006; 5:69.

91. Levis HJ, Massie I, Dziasko MA, Kaasi A, Daniels JT. Rapid tissue engineering of biomimetic human corneal limbal crypts with 3D niche architecture. Biomaterials. 2013; 34(35):8860-8.

92. Rana D, Zreiqat H, Benkirane-Jessel N, Ramakrishna $S$, Ramalingam $M$. Development of decellularized scaffolds for stem cell-driven tissue engineering. J Tissue Eng Regenerat Med. 2015; 11(4): 942-65.
93. Groebe K, Mueller-Klieser W. Distributions of oxygen, nutrient, and metabolic waste concentrations in multicellular spheroids and their dependence on spheroid parameters. Eur Biophys J. 1991; 19(4):169-81.

94. Takahashi K, Mitsui M, Takeuchi K, Uwabe Y, Kobayashi K, Sawasaki Y, Matsuoka T. Preservation of the characteristics of the cultured human type II alveolar epithelial cells. Lung. 2004; 182(4):213-26.

95. Brophy CM, Luebke-Wheeler JL, Amiot BP, Khan H, Remmel RP, Rinaldo P, Nyberg SL. Rat hepatocyte spheroids formed by rocked technique maintain differentiated hepatocyte gene expression and function. Hepatology. 2009; 49(2): 578-6.

96. Ninomiya $H$, Winklbauer $R$. Epithelial coating controls mesenchymal shape change through tissue-positioning effects and reduction of surface-minimizing tension. Nat. Cell Biol. 2008; 10(1):61-71.

97. Marga F, Neagu A, Kostzin I, Forgacs G. Developmental biology and tissue engineering. Birth Defects Res. Part C. 2007; 81(4):320-8.

98. Lin R-Z, Chou L-F, Chien C-CM, Chang H-Y. Dynamic analysis of hepatoma spheroid formation: roles of E-cadherin and b1-integrin. Cell Tissue Res. 2006; 324(3):411-22.

99. Sukach AN. Characteristics of human embryonic neuronal cells procured by nonenzyme method. Tsitologiia. 2005; 47(3):207-13.

100. Ivascu A, Kubbies M. Rapid generation of singletumor spheroids for high-throughput cell function and toxicity analysis. J. Biomol. Screen. 2006; 11(8):922-32.

101. Ma HL, Jiang Q, Han S, Wu Y, Cui Tomshine J, Wang D, Gan Y, Zou G, Liang X. Multicellular tumor spheroids as an in vivo-like tumor model for threedimensional imaging of chemotherapeutic and nano material cellular penetration. Mol. Imaging. 2012; 11 (6):487-98.

102. Cui X, Dini S, Dai S, Bi J, Binder BJ, Green JEF, Zhang $H$. A mechanistic study on tumour spheroid formation in thermosensitive hydrogels: experiments and mathematical modelling. $R S C A d v .2016$; 6(77):73282-91. 
103. Yuhas JM, Li AP, Martinez AO, Ladman AJ. A simplified method for production and growth of multicellular tumor spheroids. Cancer Res. 1977; 37(10):3639-43.

104. Foty $R$. A simple hanging drop cell culture protocol for generation of 3D spheroids. Journal of Visualized Experiments. 2011; 51:2720.

105. Oliveira MB, Neto AI, Correia CR, Rial-Hermida MI, Alvarez-Lorenzo C, Mano JF. Superhydrophobic chips for cell spheroids high-throughput generation and drug screening. ACS Appl. Mater. Interfaces. 2014; 6(12): 9488-95.

106. McMillan KS, McCluskey AG, Sorensen A, Boyd M, Zagnoni $M$. Emulsion technologies for multicellular tumour spheroid radiation assay. Analyst. 2016; 141(1):100-10.

107. Kim JB. Three-dimensional tissue culture models in cancer biology. Semin. Cancer Biol. 2005; 15:365-77.

108. Ingram M, Techy GB, Saroufeem R, Yazan O, Narayan $K S$, Goodwin TJ, Spaulding GF. Three-dimensional growth patterns of various human tumor cell lines in simulated microgravity of a NASA bioreactor. In Vitro Cell. Dev. Biol. Anim. 1997; 33(6):459-66.

109. Haisler WL, Timm DM, Gage JA, Tseng $H$, Killian TC., Souza GR. Three-dimensional cell culturing by magnetic levitation. NatProtoc. 2013; 8(10):1940-9.

110. Brophy CM, Luebke-Wheeler JL, Amiot BP, Khan H, Remmel RP, Rinaldo P, Nyberg SL. Rat hepatocyte spheroids formed by rocked technique maintain differentiated hepatocyte gene expression and function. Hepatology. 2009; 49(2):578-86.

111. Chen K, Wu M, Guo F, Li P, Chan CY, Mao Z, Li S, Ren L, Zhang $R$, Huang TJ. Rapid formation of sizecontrollable multicellular spheroids via $3 \mathrm{D}$ acoustic tweezers. Lab. Chip. 2016; 16(14):2636-43.

112. Alhasan L QiA, Al-Abboodi A, Rezk A, Chan PPY, Iliescu $C$, Yeo $L Y$. Rapid enhancement of cellular spheroid assembly by acoustically driven microcentrifugation. ACS Biomater. Sci. Eng. 2016; 2:1013-22.

113. Sebastian A, Buckle AM, Markx GH. Tissue engineering with electric fields: Immobilization of mammalian cells in multilayer aggregates using dielectrophoresis. Biotechnol. Bioeng. 2007; 98(3):694-700.

114. Mironov V, Visconti RP, Kasyanov V, Forgacs $G$, Drake CJ, Markwald RR. Organ printing: tissue spheroids as building blocks. Biomaterials. 2009; 30(12):2164-74.

115. Curcio E, Salern So, Barbieri G, De Bartolo L, Drioli E, Bader A. Mass transfer and metabolic reactions in hepatocyte spheroids cultured in rotating wall gas-permeable membrane system. Biomaterials. 2007; 28(36): 5487-97.

116. Griffith LG, Swartz MA. Capturing complex 3Dtissue physiology in vitro. Mol Cell Biol. 2006; 7(3):211-24.

117. Lin RZ, Chang HY. Recent advances in 3-D-multicellular spheroid culture for biomedical research. Biotechnology. 2008; 3(9-10):1172-84.

118. Glicklis R, Merchuk JC, Cohen S. Modeling mass transfer in hepatocyte spheroids via cell viability, spheroid size, and hepatocellular functions. Biotechnol. Bioeng. 2004; 86(6):672-80.

119. Anada T, Fukuda J, Sai Y, Suzuki O. An oxygenpermeable spheroid culture system for the prevention of central hypoxia and necrosis of spheroids. Biomaterials. 2012; 33(33):8430-41.

\section{Системи тривимірного культивування клітин}

О. М. Сукач, М. В. Шевченко

В огляді обговорюються особливості тривимірних систем культивування клітин на носіях (скафолдах) i без носіїв. Скафолди використовують 3 метою імітації позаклітинного матриксу, а також для відтворення природного фізичного і структурного мікрооточення клітин, подібного живій тканині. В огляді розглядаються типи скафолдів (жорсткі і гелевидні, природні та штучні, що розкладаються і не розкладаються), їх характеристики, переваги, недоліки та особливості заселення клітинами. Обговорюється використання в якості скафолдів децеллюлялізованих і девіталізованих органів і тканин. Також в огляді розглядається безматриксне культивування клітин у складі тривимірних багатоклітинних структур - сфероїдів. Обговорюється структура і біологія сфероїдів. Розглядаються особли- 
вості утворення сфероїдів в статичних (самозбірка) i динамічних (під впливом зовнішніх сил) умовах культивування. Обговорюється роль розміру сфероїдів для виживання клітин.

К л юч о в і с л о в а: клітини, 3D клітинна культура, скафолди, сфероїди.

\section{Системы трехмерного культивирования клеток}

А. Н. Сукач, М. В. Шевченко

В обзоре обсуждаются особенности трехмерных систем культивирования клеток на носителях (скаффолдах) и без носителей. Скаффолды используют с целью имитации внеклеточного матрикса, а также для воссоздания естественного физического и структурного микроокружения клеток, подобного живой ткани. В обзоре рассматриваются типы скаффолдов (жесткие и гелеобразные, природные и искусственные, разлагае- мые и не разлагаемые), их характеристики, преимущества, недостатки и особенности заселения клетками. Обсуждается использование в качестве скаффолдов децеллюлялизированных и девитализированных органов и тканей. Также в обзоре рассматривается безматриксное культивирование клеток в составе трехмерных многоклеточных структур - сфероидов. Обсуждается структура и биология сфероидов. Рассматриваются особенности образования сфероидов в статических (самосборка) и динамических (под воздействием внешних сил) условиях культивирования. Обсуждается роль размера сфероидов для выживания клеток.

Кл юч е в ы е сл о в а: клетки, 3D культура клеток, скаффолды, сфероиды. 